\title{
Souls and Sentientism
}

\author{
Richard D. Ryder \\ Devon, England
}

This paper was originally prepared for a conference scheduled for June 1990 in Colchester, England on "The Souls of Animals." The conference was subsequently cancelled.

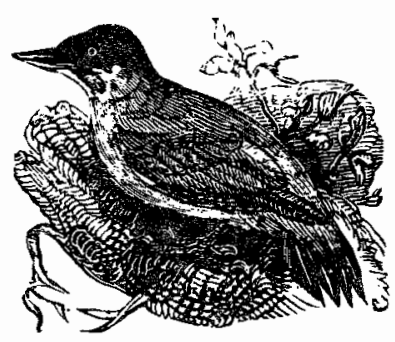

I am a psychologist and not a theologian, so I do not know what the word "soul" means. What matters to me is a creature's capacity to feel, to suffer and to be conscious; its sentiency, not its soul, is the bedrock of my concern. Let us proclaim this creed of sentientism: that anything, human or nonhuman, terrestrial or extraterrestrial, natural or man-made, that can suffer should be included within the circle of our compassion and morality.

Having admitted that I am not a theologian I must also confess that I am not religious. Religions, historically, have offered power, purpose and a programme. They have provided humankind with three things: magic, meaning and morality. Science has now taken over two out of three of those roles; it has provided the magic in abundance and the meaning partially, through technology and scientific explanation. What it has not done, however, is to provide a morality. That is why science today is in crisis--a crisis of trust in its relationship with the world. Science, like Frankenstein's monster, represents reason on the rampage.

But what can religion offer? At least religion admits of morality. All major religions have shown some concern for the sufferings of others and have suggested

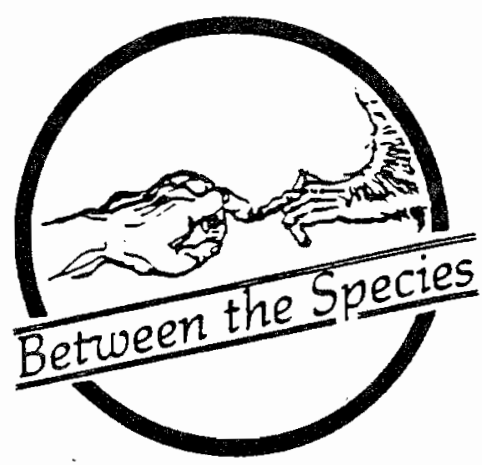

that it is wrong to do to others what we would not like done to ourselves. "Love thy neighbor" is the Christian expression of this principle. The only problem is in the definition of "neighbor"-does it mean members of my family, my tribe, my nation, my race, my species, my order or of all creation? If so, does that include the inanimate as well as the animate and the insentient as well as the sentient? It is often remarked that Christianity, of all the major religions, has least taught respect for species other than our own.

Of course there has been human weakness--those German church leaders who supported Nazi antisemitism, the foul atrocities of the Inquisition, and the barbarities of the Crusades are examples. But how far were such crimes against humanity consistent with doctrine? Did the core of Christian teaching condone such atrocities? Would Jesus have condoned them? The answer is "no." Speaking as an outsider, and I hope humbly, it seems to me that such unneighborliness represents aberration from Christ's central teaching. How far then does the obvious speciesism of Christians today and in the past represent the teachings of Christ? I would like to say, as a historian and psychologist, just this:

I cannot believe that Jesus would have condoned cruelty of any sort. The whole essence of what he preached in the Gospels is Love and Compassion. Christianity was a reaction against the fascism of the

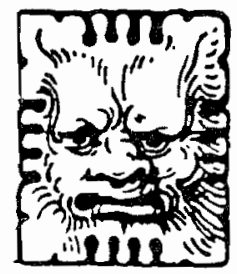

\section{RELIGION}


Roman state, a culture which cultivated cruelty as a martial virtue. Jesus was rejecting this.

Buddhism and Hinduism went much further than Jesus, of course, in specifically teaching a respect for animal life. The doctrine of Ahimsa, or non-violence, like vegetarianism, was well-established in India at the time of the Roman Empire. For centuries since then the strangely bloodthirsty and carnivorous West has done its best to destroy Buddhist and Hindu attitudes. But it is worth mentioning, in passing, that the main emphasis in India was upon life rather than sentiency. There was a duty not to kill, but not a duty actively to take steps to stop suffering.

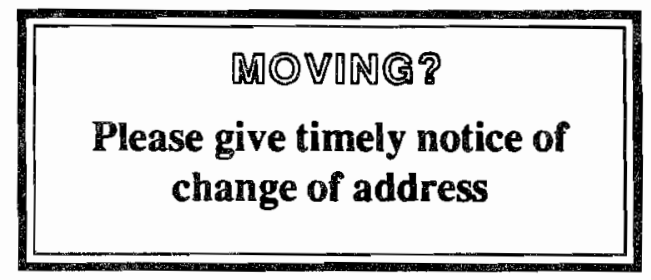

This is not the place to summarize the whole history of changing attitudes toward nonhumans. That mammoth task is beyond me, but you can read my book Animal Revolution to see my attempts to tackle at least part of that large and neglected subject. Suffice it to pick out one or two points relevant to Christianity.

First, it is sometimes assumed that Christian teaching has made some progress, albeit extremely slow progress, toward a greater respect for animals. St. Francis is seen as the originator and pioneer in this scenario. I fear this is almost the exact opposite of the truth. In fact there is evidence that Christian attitudes during the first millennium were more gentle to animals than they have been during the second. Some prayers of the Eastem Orthodox Church and the stories told about the lives of the early Saints support this. In the fourth century, St. John Chrysostom had preached kindness to animals. He was a powerful influence in the Byzantine Church and is even quoted as saying:

The Saints are exceedingly loving and gentle to mankind and even to brute beasts.... Surely we ought to show them great kindness and gentleness for many reasons, but above all, because they have the same origin as ourselves.

In the Liturgy of St. Basil of Caesaria, of the same period, can be found this prayer:
The Earth is the Lord's and the fulness thereof. O God, enlarge within us the sense of fellowship with all living things, our brothers the animals to whom Thou has given the earth as their home in common with us. We remember with shame that in the past we have exercised the high dominion of man with ruthless cruelty, so that the voice of the earth, which should have gone up to Thee in song, has been a groan of travail. May we realize that they live, not for us alone, but for themselves and for Thee, and that they love the sweetness of life.

Both these texts are remarkable and explicit in their compassion. Isaac Syrus, the seventh century Bishop of Ninevah, said that a charitable heart "is burning with charity for the whole of creation, for men, for the birds, for the beasts, for the demons-for all creatures." (Bradley, p. 94). Many other saints and early churchmen are portrayed performing individual deeds of mercy to animals: St. Jerome (373-420), like the Roman slave Androcles, is credited with laking a thom from the paw of a lion who repaid him by becoming a vegetarian and serving the monastery until he joined St. Jerome in death. St. Columba, so it is told, ordered his monks to care for an exhausted crane, and his follower, St. Walaric, was wont to caress the woodland birds. Some saints even anticipated the peaceful tactics of the modern Animal Liberation Front: St. Neot saving hares and stags from huntsmen, and the twelfth century Northumbrian, St. Godric of Finchdale, rescuing birds from snares.

St. Aventine, who lived around 438 in Gascony, rescued a stag from the hunters. St. Carileff (c 540) protected a bull that was being hunted by King Childebert, and both St. Hubert (646-727?) and the Roman General St. Eustace (died 118) saw visions of the crucifixion between the antlers of stags they were hunting; in the case of St. Hubert this led to his renunciation of the pleasures of the chase. St. Monacella (c 604, in Wales) is said to have protected a hare from the hounds, as did St. Anselm (1033-1109) and St. Isidore in Spain about a century later. The tremendously influential St. Benedict, too, counselled against eating red meat; in his famous Rule it is forbidden, except for those who are sick. In 1159, a monk of Whitby, who was living in Eskdale, rescued a wild boar from the hunt. So outraged were the huntsmen at the disruption of their sport by 
this early hunt saboteur that they attacked and mortally wounded him. The abbot rallied to the support of the hermit who, before he died, forgave his murderers but ordered them, as a penance, to build a breakwater on the beach to prevent erosion of the land. Until the twentieth century this penance was remembered by the driving in of stakes into the sand on each Ascension Day. The hermit of Eskdale surely must rank as one of the first great environmentalists, showing concern for wildlife and for habitat alike.

Another was St. Kevin of Glendalough, who opposed the building of a monastery on the Wicklow Hills because it would sadden the wild creatures. The remarkable St. Cuthbert, too, was fond of wild animals and seems to have felt a sense of unity with them. A seventh century Scottish shepherd boy, he was fifteen when he became a monk in Melrose Abbey. Later, he became a hermit, living on Farne Island in a small cell. There he made friends with the birds, giving them his protection from the depredations of men and, so the story goes, receiving food from them in return, as they shared their meals together.

Whether or not these stories are historical fact, it is true that they were part of Church lore for many centuries. If such compassion for beasts was attributed to the saints, it is clear that many ordinary men and women would have striven to follow their example. Regardless as to what the theologians were saying at the time, kindness to nonhumans must have been widely regarded as a saintly virtue.

In general, perhaps, later Christian theologians have not really faced up to the issue; rather than being actively speciesist, they have ignored the problems intrinsic in the human-nonhuman relationship. Yet many in the Catholic Church continued to follow Aquinas' line, and as late as the nineteenth century, Pope Pius IX refused to allow the foundation of a society to protect animals in Rome on the grounds that human beings had no duties toward lower creation.

St. Francis can thus be seen as the tail-end of a wonderful neighborly tradition. Why did things change? I fear it was Thomas Aquinas-ironically nicknamed "the slow ox"-who did most of the damage. Perhaps because of some personal sensitivity about this nickname, he announced that God did not care for oxen and that we did not have to do so either. Aquinas, of course, was as much a Greek pagan in his thinking as a genuine follower of the Gospels, and his disdain toward nonhumans is more Aristotelian than Christian.
I know it can be argued that Jesus apparently did not say very much about animals except to assure us that God cared about sparrows. (If sparrows were cared for, then why not oxen, Aquinas?) Jesus also seemed to be opposed to animal sacrifice, and he used the symbol of the good shepherd as a central image in his teaching. In many respects Jesus was still supporting the moral teaching of the Old Testament and that, as I have argued in my book, was quite compassionate toward animals. The strident St. Paul, the sexually crazed St. Augustine and the bovine St. Thomas Aquinas were deviating from much in the Old Testament in their speciesism.

As a non-religious outsider it seems to me to be extraordinary how much influence these mediaeval distorters of the faith still have on the thinking of the Church today. Some of them were half-mad, anyway, and I, for one, cannot take them at all seriously. Did they not remember what Hosea had said:

and in that day I make a covenant for them with the beasts of the field, and with the fowls of heaven, and with the creeping things of the ground: and I will break the bow and the sword and the battle out of the earth, and will make them lie down safely.

Isaiah, too, writes: "He that killeth an ox is as if he slew a man." And in the first chapter of Genesis God instructs man to be vegetarian. It is only after the Flood that God gives Noah permission to eat meat. We should also recall that God's commandment was "Thou shall not kill!" He did not say "Thou shalt not kill people!" He said, "Thou shalt not kill!" Job, too, challenged mankind's central position.

These are not the only merciful passages to be found in the Old Testament. Cattle are to be allowed to rest on the Sabbath; oxen treading the corn should not be muzzled; kids should not be cooked in their mother's milk; parent birds should not be taken if sitting on eggs or with their young; and men are enjoined not to yoke together the ox and the ass. Proverbs recognizes that a "righteous man regardeth the life of his beast," and in Ecclesiastes it is stated that "a man hath no preeminence above a beast: for all is vanity." Even the strict injunctions of the Old Testament against sexual union between human and nonhuman were similar to those against incest; nonhuman animals were in this respect to be regarded rather as relatives. 
Of course much of the argument was about Genesis and the so-called "dominion over the animals" that God is supposed to have given humankind. Thankfully, that word is now more frequently being translated as stewardship. Generally speaking, it seems that the Hebrews may have become less speciesist in later centuries.

One of the numerous advantages of having children of school age is that they bring home their homework. Emily recently asked me to help her with the plagues of Egypt, and in her new translation Bible I came across a most interesting version (Exodus 8, verse 26) of what Moses said to Pharoah when the latter suggested the Israelites could sacrifice animals to their God while still remaining in Egypt. "If the Egyptians see us," asks Moses, "will they not stone us to death?" The reason given is that "the Egyptians would be offended by our sacrificing the animals." This is just a little further clue that the Israelites, in their earlier history, were more murderous of animals than were their Egyptian masters, who clearly had strong views on such issues.

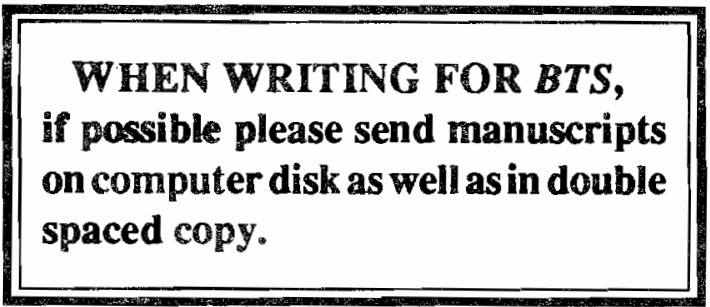

Finally, a word about consciousness. Consciousness is the great, unexplained mystery which has, until recently, been neglected by science. Our consciousness seems to increase when there is a crisis, and much of what we do daily remains unconscious. But is it enough to say that consciousness is a mechanism for dealing with crises? Of course not. That may be part of its function, but not its origin and explanation. It is also unclear whether consciousness has survival value; that is to say, although it may be associated with coping with crises or helping us to relate to others, would it not be possible for such functions (admittedly of considerable survival value) to be carried out unconsciously? Consciousness seems to be an unnecessary requirement here.

Some have argued that quantum theory helps to explain the phenomenon of consciousness. Quantum events are essentially holistic; they consist of both a particular and a wave-like nature. Consciousness itself is holistic--it emerges from millions or billions of particular neural events and yet has a smoothness, and a quality, entirely different from the neural impulses themselves. The unexplained principle of emergence is a key concept.

It is, of course, possible to step back from all this and question whether we are not trying to explain consciousness in terms of quantum theory merely because they are the two most extraordinary mysteries that science is currently faced with. But there are other reasons for seeing a possible connection between quantum theory and consciousness, most notably the concern with "the observer." In quantum theory it is argued that the act of observation itself determines reality. That is to say, the world of atoms and subatomic particles is nebulous and only sharpens into concrete form when it is observed. Now, I propose equating observation with consciousness. Once done, we have a further reason for regarding consciousness with special reverence: as an active and powerful part of the universe, not just a figment.

Consciousness is of paramount importance to all of us. By definition it is the universe of our awareness. On the assumption that many other species are conscious or sentient I have suggested that our morality is based upon a concern for all sentients-which I have called sentientism, although I could equally have called it consciousism (but that is even more horrible as a word!). Pain and pleasure are the two great poles of consciousness, between which all sentients swing; striving to gain one and avoid the other. Even here, the position of the observer is crucial. How do we calculate whether an action is right or wrong other than an assessment of its pleasurable and painful consequences? We cannot aggregate the pains and pleasures of different individuals because consciousness itself apparently does not escape from one individual to another; my consciousness is always mine and never yours-I am always me and never you. So morality becomes a matter of looking at things selfishly or, alternatively, altruistically; that is to say, respectively, from my point of view or, as far as is possible, from someone else's point of view. Or perhaps even from an imagined totally external point of view.

Just as the observer issue may play a part in our morality, so it may also play a part in the phenomenon of holism and emergence; indeed both may only exist in our minds. Consciousness may be an emergent property of brain, and emergence may be a property of consciousness. Either way, or both, consciousness is 
all we have, and even if soul and consciousness are the same thing, that thing is the foundation on which we must build our new morality. It is a morality which does not discriminate between sexes, races, orders, nor species, nor even between animate and inanimate, but on the sole grounds of whether there is or is not consciousness which is being affected by our actions.

If soul means consciousness, then I am for it.

\section{References}

Ian Bradley, God is Green (Darton, Longman and Todd, 1990). Richard D. Ryder, Speciesism (1970) (leaflets)

Richard D. Ryder, Victims of Science (Centaur Press, 1975).

Richard D. Ryder, Animal Revolution (Basil Blackwell, 1989).

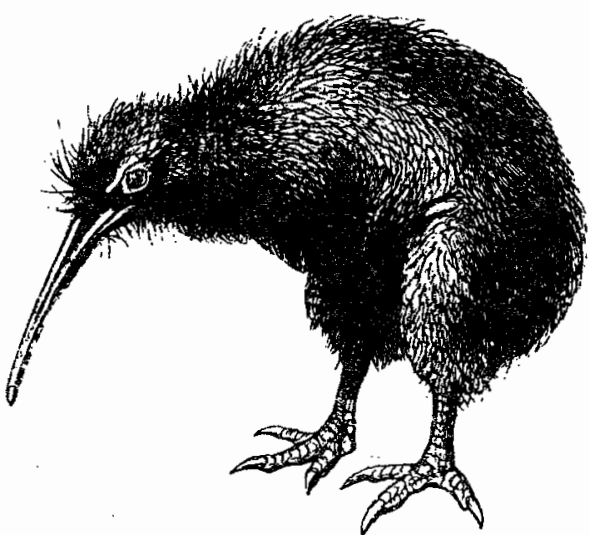

\section{CALL FOR PAPERS}

\section{International Conference on}

\section{Science and the Human-Animal Relationship}

5 - 7 March, 1992

Amsterdam, The Netherlands

The question of animal experimentation has been individually addressed by scientists, ethicists, and organized groups concemed with animal suffering. The purpose of this conference is to generate interdisciplinary consideration of this question. To that end four thematic approaches have been chosen:

- the influence of natural science on the humananimal relationship;

- the human-animal relationship as an object of social research;

- animals and the cult (culture) of natural science;

- animal care (ethical) committees between the scientific community and government.

These themes will be considered in the context of presentations and workshops. Special evening programmes will be conducted on the regulation of research with transgenic animals and the therapeutic use of animals by humans.

Papers: Those interested in presenting a paper on any one of the four themes are requested to send an abstract (500 words) before 1 October, 1991 to Dr. E. K. Hicks, SISWO, P. O. Box 19079, $1000 \mathrm{~GB}$ Amsterdam, The Netherlands. Tel: (31) (20-) 5270600; Fax: (31) (20-) 6229430. Two volumes are planned for publication: a conference proceedings and a reader of selected papers. Should you wish to have your paper considered for publication in the latter, it must be received by Dr. Hicks before 1 February, 1992.

Jointly organized by the Institute for the Study of the Human-Animal Relationship and the Netherlands Universities' Institute for the Coordination of Research in the Social Sciences (SISWO). 